\title{
The Mediating Role of Emotional Exhaustion and Job Satisfaction on the Relationship Between Job Demands and Instigated Workplace Incivility
}

\author{
Vui-Yee Koon' ${ }^{(D)}$ and Pui-Yi Pun'
}

\begin{abstract}
High job demands are considered a risk factor for uncivil behavior in the workplace but the mechanism behind this relationship remains unclear. The current study aimed to analyze emotional exhaustion and job satisfaction as sequential mediators of the relationship between job demands and instigated workplace incivility within the integrative framework of affective events theory and the job demand-control model. Data were collected from 102 university academic staff in Klang Valley, Malaysia, via snowball sampling method. The results supported the predicted three-path mediation model with age, gender, and employment contract type as covariates. High job demands led to emotional exhaustion, which, in turn, led to a decrease in job satisfaction level and as a result gave rise to instigated workplace incivility. Implications, limitations of these findings, and directions for future research are further discussed on how to enhance and establish a civil and respectful workplace.
\end{abstract}

\section{Keywords}

emotional exhaustion, job demands, job satisfaction, instigated workplace incivility, sequential mediating

\section{ISunway University, Selangor Darul Ehsan, Malaysia}

\section{Corresponding Author:}

Vui-Yee Koon, Sunway University, No. 5, Jalan Universiti, Bandar Sunway, 47500 Selangor Darul Ehsan, Malaysia.

Email: vuiyeek@gmail.com 


\section{Introduction}

Researchers have defined workplace incivility in various ways since the late 1990s (Andersson \& Pearson, 1999; Lutgen-Sandvik, 2003; Zauderer, 2002) but the underlying common definition shared by these researchers is that workplace incivility is a "low-intensity deviant behaviour with ambiguous intent to harm the target, in violation of workplace norms for mutual respect" (Andersson \& Pearson, 1999, p. 457). This indicates that the intention of an uncivil act or behavior is ambiguous and can be interpreted differently by the instigator, the target, or even an observer. While the reason for the incivility is unclear, the spillover effects of incivility could be significantly detrimental (Cortina, Kabat-Farr, Leskinen, Huerta, \& Magley, 2013).

There is a rising concern over instigated workplace incivility (Estes \& Wang, 2008), and according to Pearson, Andersson, and Porath (2000), the detrimental effects of uncivil behaviors in an organization are beyond the anticipation of many managers. Research has indicated that instigated workplace incivility leads to low job satisfaction, low organizational commitment, and high job turnover intention (V. K. Lim \& Teo, 2009), thereby affecting organizational performance and lowering the profitability of the business (Estes \& Wang, 2008). Additionally, a Malaysian news outlet reported that business costs arising from instigated workplace incivility could amount to RM 59,220 per employee annually (De Pater, 2015). As such, it is important to understand instigated workplace incivility better.

Doshy and Wang (2014) highlighted the need to identify and eliminate the underlying causes of instigated workplace incivility. Previous studies tended to focus on the negative consequences of instigated workplace incivility and recent researchers (Blau \& Andersson, 2005; Holm, Torkelson, \& Bäckström, 2015; Meier \& Semmer, 2013; Schilpzand, De Pater, \& Erez, 2014; Torkelson, Holm, Bäckström, \& Schad, 2016) have called for more studies to be conducted on its antecedents or causes. According to Schilpzand et al. (2014), the number of studies concerning the instigation of workplace incivility is relatively smaller compared with the number of studies concerning employees' experience of workplace incivility. As stressed by Estes and Wang (2008), incivility should be explored in an organizational context, and according to Meier and Semmer (2013), studying the antecedents of instigated workplace incivility could enlighten us to its solutions. Therefore, the current study explored the antecedents of instigated workplace incivility with a focus on organizational factors, specifically job demands.

In addition to the minimal research done on the antecedents of instigated workplace incivility, there is also a lack of research on possible mediators of instigated workplace incivility (Cortina, Magley, Williams, \& Langhout, 2001; Holm et al., 2015; Martin \& Hine, 2005; Schilpzand et al., 2014; Torkelson et al., 2016). The lack of focus on possible mediators in research could explain the weak relationship found between job demands and instigated workplace incivility (Cortina et al., 2001; Torkelson et al., 2016), and hence, there is a need to explore mediators as the underlying mechanism of how such incivility arises in the workplace (Schilpzand et al., 2014). Research has found emotional exhaustion to be a powerful mediator on the relationship between 
customers' incivility and employees' incivility (van Jaarsveld, Walker, \& Skarlicki, 2010), while job satisfaction has strong associations with emotional exhaustion (Hur, Kim, \& Park, 2015) and instigated workplace incivility (Blau \& Andersson, 2005), respectively. Therefore, this study examined the mediating roles of emotional exhaustion and job satisfaction on the relationship between job demands and instigated workplace incivility to shed more light on instigated workplace incivility.

Our conceptual framework was based on the integration of Karasek's (1979) Job Demand-Control (JDC) model with Weiss and Cropanzano's (1996) affective events theory (AET). According to Karasek, the JDC model describes the roles of job demands and job decision latitude/job control in relation to workplace stress and suggests that employees with extensive job demands but minimal level of control may face higher work stress, which, in turn, leads to dissatisfaction at work (Saif-ur-Rehman, Rasli, \& Al-Harthey, 2011). The JDC model was used in previous studies of experienced and instigated workplace bullying (Baillien, De Cuyper, \& De Witte, 2011; Notelaers, Baillien, Witte, Einarsen, \& Vermunt, 2013), and a study by Torkelson et al. (2016) found a direct relationship between job demands and instigated workplace incivility. However, this direct relationship was a weak one, implying that job demands alone did not completely influence instigated workplace incivility. Karasek's JDC model alone is insufficient to explain the job demands-instigated workplace incivility relationship, and hence, we integrated AET into our conceptual framework.

AET postulates that features of the work environment, such as job control, intense workload, limited promotion and job opportunities, and salary structure, influence job attitude and, in turn, work behavior (Wegge, van Dick, Fisher, West, \& Dawson, 2006; Weiss \& Cropanzano, 1996). Integrating AET into our conceptual framework provides a better understanding of the job demands-instigated workplace incivility relationship by examining the affective and emotional states of employees that lead them to exhibit a certain behavior (Briner, 1999; Glasø, Vie, Holmdal, \& Einarsen, 2011). Past studies have used AET to explain observers' response toward instigators of workplace incivility (Reich \& Hershcovis, 2015), emotional states of employees who experienced instigated workplace incivility (Bunk \& Magley, 2013), how workplace rudeness triggers uncivil workplace behavior (Reio \& Ghosh, 2009), and consequences of instigated workplace incivility (S. Lim, Cortina, \& Magley, 2008). However, research has not looked into how emotional states due to work environment affects instigated workplace incivility. As such, our study posited that job demands, a feature of work environment, influences instigated workplace incivility (work behavior) through emotional exhaustion (emotional state) and job satisfaction (job attitude).

\section{Theory and Hypotheses}

\section{Job Demands and Emotional Exhaustion}

Job demands are defined as "those physical, social, or organizational aspects of the job that require sustained physical or mental effort and are therefore associated with certain physiological and psychological costs" (Demerouti, Bakker, Nachreiner, 
\& Schaufeli, 2001, p. 501). Examples of job demands include intense workload and pressure, along with emotionally taxing interactions with clients (Bakker, van Veldhoven, \& Xanthopoulou, 2010). Job demands are a commonly known stressor in any organization (Tremblay \& Messervey, 2011) and have been linked to various signs of job strain such as anxiety and depression (Diestel \& Schmidt, 2009; Griffin, Greiner, Stansfeld, \& Marmot, 2007). Tremblay and Messervey (2011) further emphasized that chronic job demands such as work overload may cause job strain on a long-term basis. Previous studies found that low control over job demands is closely linked to workplace bullying (Baillien et al., 2011; Glasø \& Notelaers, 2012), which is also related to organizational antecedents of pressure at work, performance demand, unsatisfactory social environment, and unclear job roles (Agervold, 2009). Another study by Francis, Holmvall, and O'Brien (2015) suggested that employees with high workload are likely to exhibit deviant behavior in the workplace. Therefore, high job demands in the workplace is likely to shape the behavior of employees.

Emotional exhaustion, which can be defined as "feelings of being emotionally overextended and depleted of one's emotional resources" (Maslach, 1993, pp. 20-21), reflects the individual strain dimension of burnout (Halbesleben \& Bowler, 2005). Burnout is a multidimensional construct comprising emotional exhaustion, depersonalization, and reduced personal accomplishment (Maslach, 1993). Our current study focused on emotional exhaustion, whereby employees experience feelings of tension and frustration as they fear that they are unable to provide consistent work performance (Cordes \& Dougherty, 1993). Consistent with the JDC model, extensive job demands lead to high strain among employees, making them feel emotionally exhausted when they have nothing more to give to maintain their work performance. In light of this, emotional exhaustion has been gaining attention in workplace burnout research (van Jaarsveld et al., 2010).

In relation to job demands, O'Moore (2000) defined emotional exhaustion at work as the "depletion of emotional and mental energy needed to meet job demands" (p. 336). As such, job demands and emotional exhaustion could be interrelated. Past research tended to focus on how uncivil behavior by customers affects emotional exhaustion. For example, Sliter, Pui, Sliter, and Jex (2011) found that employees experience emotional exhaustion due to customer incivility, while Karatepe, Yorganci, and Haktanir (2009) reported a positive relationship between customers' verbal aggression and emotional exhaustion. Other researchers have theorized that employees are more likely to experience negative mood, cognitive distraction, and fear due to disrespectful behavior at work (Barling, 1996; Barling, Rogers, \& Kelloway, 2001). Dealing with customers or clients is a type of job demands although there is minimal research that explicitly investigated the influence of job demands on employees' emotional exhaustion. Therefore, we assumed job demands lead to emotional exhaustion and proposed the following hypothesis:

Hypothesis 1: Job demands are positively related to emotional exhaustion. 


\section{Emotional Exhaustion and Job Satisfaction}

Job satisfaction is a work attitude that can be defined as "a pleasurable or positive emotional state resulting from the appraisal of one's job or job experiences" (Locke, 1976, p. 1300). Majority of past studies focused on how emotional exhaustion affects work behavior but not work attitude. For example, researchers found that emotional exhaustion affects work performance (Rutherford, Boles, Hamwi, Madupalli, \& Rutherford, 2009) and that emotionally exhausted employees are likely to display counterproductive work behavior in order to relieve negative emotions (Banks, Whelpley, Oh, \& Shin, 2012; Sakurai \& Jex, 2012). These counterproductive work behaviors include low job performance (Swider \& Zimmerman, 2010) and low organizational citizenship behavior (Cropanzano, Rupp, \& Byrne, 2003). According to Saari and Judge (2004), employees' intention to behave in a certain way could also be a result of their job attitude. As such, the relationship between emotional exhaustion and work behavior should be examined together with job attitude.

According to AET, people experience a variety of emotions - betrayal, annoyance, anger, frustration, pride, or even joy - with each emotion resulting in different behaviors. Dugguh and Dennis (2014) addressed the importance of employees' emotion management, whereby pleasant emotions are maintained through a combination of conscious and unconscious efforts and, as a result, job satisfaction increases. A recent study found that emotional exhaustion negatively affects job satisfaction in the workplace (Hur et al., 2015). Hence, we expected that emotional exhaustion influences job attitudes and proposed the following hypothesis:

Hypothesis 2: Emotional exhaustion is negatively related to job satisfaction.

\section{Job Satisfaction and Instigated Workplace Incivility}

Workplace incivility comprises three types: experienced, witnessed, and instigated (Schilpzand et al., 2014). In our study, we only examined instigated workplace incivility, focusing on the characteristics and attitudes of employees who display uncivil behavior in the workplace. Some common examples of instigated workplace incivility include taking advantage of work and ideas of others, generating rumors about colleagues, not providing encouragement to subordinates, ignoring requests of colleagues, yelling at colleagues, and undervaluing colleagues' opinions that are different (Estes \& Wang, 2008; Torkelson et al., 2016). A recent study found that organizational changes, job insecurity, minimal social support from coworkers and supervisors, intensified job demands, and low autonomy over job scope are potential organizational factors that lead to workplace incivility (Torkelson et al., 2016). Additionally, Blau and Andersson (2005) demonstrated that distributive justice, job satisfaction, and work exhaustion are closely related to instigated workplace incivility, while Pearson et al. (2000) stated that shifts in power and growing job demands lead to unchecked incivility in the workplace. Unsurprisingly, employees' ability to interact in a polite 
manner would also be affected when they experience work overload (van Jaarsveld et al., 2010).

In line with AET, previous research showed that employees are more likely to engage in deviant workplace behavior if they are unhappy with their current work conditions (Bennett \& Robinson, 2000). One way to measure happiness at work is to look at job satisfaction (Locke, 1976), which reflects employees' emotional attachment to their jobs (Meyer, Allen, \& Smith, 1993). Past research has found a negative relationship between job satisfaction and deviant work behaviors, whereby a decrease in job satisfaction led to an increase in chronic lateness and unexcused absence (Blau, 1994) as well as rude behavior among employees (Blau \& Andersson, 2005). A metaanalytic review found workplace incivility among supervisors, coworkers, and outsiders has an effect on attitudinal outcomes, such as job satisfaction (Herschcovis \& Barling, 2010) but did not measure the competing relationship of the two studied variables. We expected a negative relationship between job satisfaction and instigated workplace incivility, whereby job satisfaction affects instigated workplace incivility. Hence, we proposed the following hypothesis:

Hypothesis 3: Job satisfaction is negatively related to instigated workplace incivility.

\section{The Mechanism Linking Job Demands and Instigated Workplace Incivility}

Past studies on burnout in the workplace have found a link between job demands and emotional exhaustion (Cordes \& Dougherty, 1993; Maslach \& Pines, 1977). Karasek's (1979) JDC model particularly describes the role of job demands in relation to workplace stress, believing that it leads to emotional exhaustion. The JDC model suggests that employee experience job strain when they have extensive job demands, which would also affect job satisfaction (Saif-ur-Rehman et al., 2011). It has also been noted that work overload and information overload put employees under time pressure, which decreases their tendency to behave politely at work (Pearson et al., 2000). Furthermore, studies have found that emotionally exhausted employees are more likely to exhibit rude behavior in the workplace (van Jaarsveld et al., 2010).

By integrating AET and the JDC model in our study, we proposed that high job demands in the workplace cause emotional strain that influences job satisfaction, which, in turn, affects behavior. In other words, the effect of job demands on instigated workplace incivility arises due to the sequential mediating effects of emotional exhaustion and job satisfaction. Past studies have found a weak relationship between job demands and instigated workplace incivility, implying that job demands influence instigated workplace incivility through mediators (Cortina et al., 2001; Torkelson et al., 2016). Therefore, we assumed emotional exhaustion and job satisfaction to play mediating roles in the relationship between job demands and instigated workplace incivility and proposed the following hypothesis: 
Hypothesis 4: The positive relationship between job demands and instigated workplace incivility is sequentially mediated by emotional exhaustion and job satisfaction.

\section{Method}

\section{Sample and Procedure}

Due to Malaysia's transition into a knowledge economy (Arokiasamy, Ismail, Ahmad, \& Othman, 2009) and the need to match teaching quality to high societal expectations (Altbach \& Knight, 2007; Vardi, 2011), academic staff in Malaysia are currently experiencing intensified workload as they are required to fulfil a wide range of job roles. Additionally, academic staff are also expected by their employers to handle different courses within their subject specialization (Sohail, Daud, \& Rajadurai, 2006) and some of them might have neither the time nor expertise to perform all areas of their work efficiently (Vardi, 2011). As such, it would be interesting to examine whether uncivil behavior in the workplace would occur among academic staff experiencing intensified workload.

Data for the study were collected from a sample of 102 academic staff, comprising 60 females (58.8\%) and 42 males (41.2\%), from educational institutions within Klang Valley, Malaysia. Prior to data collection, we used $G^{*}$ Power to perform an a priori analysis to determine the minimum sample size our study required. The results from the analysis showed that our study required a minimum sample size of 77 participants.

Participants were recruited via snowball sampling method, whereby new participants that fit the participation criteria would be recruited by existing participants (Kumar, Abdul Talib, \& Ramayah, 2013). For our study, we first identified and distributed our survey in person to two participants that fit our participation criteria: academic staff with high job demands whose work performances are evaluated based on their teaching, research, as well as administration and other ad hoc duties. These two participants would then recruit other fellow academic staff as participants, who, in turn, would recruit more academic staff as participants. This method of recruitment continued until we reached our desired number of participants.

\section{Measures}

Job Demands. A six-item scale developed by Karasek (1979) was used to measure employees' perception on job demands. The responses were measured through a 5-point Likert-type scale, ranging from 1 (strongly disagree) to 5 (strongly agree). A sample item included, "My job requires me to work fast." The Cronbach's alpha was reported to be 840 .

Emotional Exhaustion. The job-related of emotional exhaustion scale was used to measure employees' emotional exhaustion (Wharton, 1993). Five items were rated on a 6-point Likert-type scale from 1 (never feel this way while at work) to 6 (feel this way 
every day). A sample item included, "I feel used up at the end of the work day." The Cronbach's alpha was reported to be .879 .

Job Satisfaction. To measure employees' job satisfaction, we combined three items from Job Satisfaction Scale (Warr, Cook, \& Wall, 1979) and four items from Spector's (1997) Job Satisfaction Survey. These combined items were measured on a 7-point Likert-type scale, ranging from 1 (extremely dissatisfied) to 7 (extremely satisfied). The sample items included, "I am satisfied with the amount of responsibility given" and "Now, taking everything into consideration, I am satisfied with my job." The Cronbach's alpha of this measure was found to be .892 .

Instigated Workplace Incivility. Instigated workplace incivility was measured using the seven-item Workplace Incivility Scale developed by Cortina et al. (2001) and modified by Blau and Andersson (2005). As this study focused exclusively on instigated workplace incivility, two items that measure experienced workplace incivility were removed from the scale. Taking into consideration Blau and Andersson's suggestion, responses on the Workplace Incivility Scale were measured on a 7-point Likert-type scale, where 1 = never, 2 = hardly ever (about once in every few months), 3 = rarely (about once in a month), 4 = occasionally (at least several times/month), 5 = sometimes (at least once/week), 6 = frequently (at least oncel day), and 7 = very frequently (at least several times/day). A sample item included, "I gossiped about someone behind their back." The Cronbach's alpha was reported to be .793 .

In our data analyses, we held constant age, gender, and employment contract type. Age was held constant because past studies had found younger workers to exhibit more negative behavior than older workers (O’Moore, 2000). Similarly, gender was held constant because counterproductive work behaviors were reported more often in males than females (Henle, Giacalone, \& Jurkiewicz, 2005). Employment contract type was held constant as it has been found to affect employee outcomes (Guest, 2004). In our analyses, age was self-reported in years, while gen$\operatorname{der}($ male $=0$, female $=1)$ and employment contract type (permanent $=0$, contractual $=1$ ) were dummy coded.

\section{Results}

\section{Descriptive Statistics, Correlations, and Reliabilities}

Table 1 presents the means, standard deviations, and correlations for all study variables. All correlations in our study were below .70, indicating that all measures were appropriate for usage and that the likelihood of multicollinearity in a regression is low (Tabachnick \& Fidell, 1996). Variance inflation factors (VIF) in the regression were also examined and all variables were found to have VIF values of below 2. As such, the possibility of multicollinearity in this study is minimal. 
Table I. Means, Standard Deviations, and Correlations Among the Variables.

\begin{tabular}{|c|c|c|c|c|c|c|c|c|c|}
\hline Variables & M & $S D$ & I & 2 & 3 & 4 & 5 & 6 & 7 \\
\hline I. Age (years) & 34.17 & 10.06 & - & & & & & & \\
\hline 2. Gender ${ }^{\mathrm{a}}$ & - & - & .058 & - & & & & & \\
\hline 3. Type & - & - & -.032 & $-.282^{* *}$ & - & & & & \\
\hline 4. Job demands & 3.70 & 0.68 & -.006 & -.013 & .042 & .840 & & & \\
\hline 5. Emotional exhaustion & 3.37 & 1.15 & .030 & -.079 & .145 & $.583^{* *}$ & .879 & & \\
\hline 6. Instigated workplace incivility & 4.31 & 1.07 & -.190 & -.097 & .069 & $.387 * *$ & $.552^{* *}$ & .793 & \\
\hline 7. Job satisfaction & 2.73 & 1.03 & -.034 & .036 & -.070 & $-.232 *$ & $-.309 * *$ & $-.385^{* *}$ & .892 \\
\hline
\end{tabular}

Note. Cronbach's alpha values are reported in bold in the diagonals $(N=102)$.

${ }^{\mathrm{a} G e n d e r}$, dummy coded (male $=0$, female $=\mathrm{I}$ ). ${ }^{\mathrm{b}}$ Employment contract type, dummy coded (permanent $=0$, contractual $=1$ ).

$* p<.05 . * * p<.01$

\section{Measurement Models}

Prior to further analyses, we checked on the common method variance (CMV) to ensure that there is no single principal factor that represents for the majority of the variance explained (Podsakoff \& Organ, 1986). The unrotated factor analysis showed that the first factor accounted for only $27.21 \%$ (less than $50 \%$ ) of the total $59.80 \%$ variance indicated and thus, was not a serious threat for common method bias in the study.

A series of confirmatory factor analyses using AMOS maximum likelihood were conducted to reduce the possibility of common method bias by ensuring that our measurement model fits our data. We examined the fit of a four-factor model that included job demand, emotional exhaustion, job satisfaction, and instigated workplace incivility. As expected, the proposed four-factor model demonstrated acceptable fit, $\chi^{2 /}$ degrees of freedom $(d f)=1.54$; Tucker-Lewis index $($ TLI $)=.909$; incremental fit index $(\mathrm{IFI})=.925$; comparative fit index $(\mathrm{CFI})=.923$; root mean square error of approximation $(\mathrm{RMSEA})=.074$. In addition, all factor loadings were significant, which demonstrated convergent validity. The discriminant validity of the four variables was then tested by contrasting the four-factor model against three alternative models: a three-factor model, a two-factor model, and a one-factor model. The threefactor model was obtained by loading the items measuring job demands and emotional exhaustion into one latent factor as these two constructs had the highest correlation. The two-factor model was obtained by loading the items measuring job demands, emotional exhaustion, and job satisfaction into one latent factor, while the one-factor model was obtained by loading all items of the four variables into one latent factor. Confirmatory factor analysis results suggested that the three-, two-, and one-factor models yielded poor fits to the data: three-factor model $\left(\chi^{2} / d f=1.96\right.$, TLI $=.838$, IFI $=.864, \mathrm{CFI}=.860, \mathrm{RMSEA}=.098)$, two-factor model $\left(\chi^{2} / d f=3.67, \mathrm{TLI}=.553, \mathrm{IFI}=\right.$ $.619, \mathrm{CFI}=.610, \mathrm{RMSEA}=.163)$, and one-factor model $\left(\chi^{2} / d f=4.16, \mathrm{TLI}=.471\right.$, IFI $=.546, \mathrm{CFI}=.536, \mathrm{RMSEA}=.177)$. Therefore, the discriminant validity of the variables was confirmed. 


\section{Assessment of the Structural Model}

Before interpreting the results, we checked the structural model for collinearity issues. All VIF values were below the threshold of 5, indicating that collinearity was not an issue in the structural model. The structural model was then evaluated to test our hypotheses. This study measured the total, direct, and indirect effects of the variables using PROCESS macro for SPSS, which generated percentile-based bootstrap confidence intervals (CIs) of job demands on instigated workplace incivility. The results are deemed significant if the CIs do not have values of zero.

To test for sequential mediation, Taylor, MacKinnon, and Tein's (2008) joint significance test approach was adopted. Each path of the mediational chain, with emotional exhaustion treated as Mediator 1, job satisfaction treated as Mediator 2, and instigated workplace incivility treated as the dependent variable, was tested and entailed the three individual regression models. According to MacKinnon, Lockwood, Hoffman, West, and Sheets (2002), this approach provides high statistical power with small Type I error.

Model 1: Emotional exhaustion $=\beta_{01}+\beta_{1}$ job demands $+\varepsilon_{1}$

Model 2: Job satisfaction $=\beta_{02}+\beta_{2}$ job demands $+\beta_{3}$ emotional exhaustion $+\varepsilon_{2}$

Model 3: Instigated workplace incivility $=\beta_{03}+\beta_{4}$ job demands $+\beta_{5}$ emotional exhaustion $+\beta_{6}$ job satisfaction $+\varepsilon_{3}$

The first estimated model of our study included the association between emotional exhaustion and job demands, while in the second model, job satisfaction was regressed on both job demands and emotional exhaustion. In the third model, job demands, emotional exhaustion, and job satisfaction were all included as predictors of instigated workplace incivility. Based on the joint significance test, mediation is found if the following three paths or associations are jointly significant: between job demands and emotional exhaustion $\left(\beta_{1}\right)$, between emotional exhaustion and job satisfaction $\left(\beta_{3}\right)$, and between job satisfaction and instigated workplace incivility $\left(\beta_{6}\right)$. Demographic variables such as age, gender, and employment contract type were used as control variables.

\section{Hypotheses Testing}

Table 2 shows the results of the hierarchical regression analysis of the direct and mediating effects of the examined variables. Hypothesis 1 proposed that job demands are positively related to emotional exhaustion, and as shown in Table 2, the results revealed that there was a significant positive linear relationship between job demands and emotional exhaustion $\left(\beta_{1}=1.075, p<.001\right.$, Model 1$)$. Results also supported Hypothesis 2 as there was a significant negative relationship between emotional exhaustion and job satisfaction $\left(\beta_{3}=-0.236, p<.05\right.$, Model 2$)$. Hypothesis 3 was also supported $\left(\beta_{6}=-0.201, p<.01\right.$, Model 3$)$, whereby job satisfaction was found to be negatively related to instigated workplace incivility. On the mediational chain, 
Table 2. Results of the Hierarchical Regression Analysis That Examine the Direct and Mediating Effects of the Variables.

\begin{tabular}{|c|c|c|c|c|c|c|c|c|c|}
\hline \multirow[b]{2}{*}{ Predictors } & \multicolumn{3}{|c|}{$\begin{array}{c}\text { Model I } \\
\text { (Outcome = emotional } \\
\text { exhaustion) }\end{array}$} & \multicolumn{3}{|c|}{$\begin{array}{c}\text { Model } 2 \\
\text { (Outcome }=\text { job } \\
\text { satisfaction) }\end{array}$} & \multicolumn{3}{|c|}{$\begin{array}{c}\text { Model } 3 \\
\text { (Outcome }=\text { instigated } \\
\text { workplace incivility) }\end{array}$} \\
\hline & Coeff. & SE & $p$ & Coeff. & SE & $p$ & Coeff. & SE & $p$ \\
\hline \multicolumn{10}{|l|}{ Control variables } \\
\hline Age & -.005 & .010 & .619 & .001 & .011 & .937 & -.005 & .007 & .540 \\
\hline Gender & .093 & .191 & .629 & -.060 & .210 & .776 & -.380 & .144 & .010 \\
\hline Employment contract type & .350 & .270 & .197 & -.083 & .298 & .782 & -.088 & .204 & .667 \\
\hline \multicolumn{10}{|l|}{ Antecedent } \\
\hline X (Job demand) & 1.075 & .152 & $<.001$ & -.139 & .204 & .678 & .105 & .140 & .457 \\
\hline $\begin{array}{l}\text { Mediator I (Emotional } \\
\text { exhaustion) }\end{array}$ & - & - & - & -.236 & .1111 & .036 & .342 & .078 & $<.001$ \\
\hline \multirow[t]{2}{*}{ Mediator 2 (Job satisfaction) } & - & - & - & - & - & - & -.201 & .070 & .005 \\
\hline & \multicolumn{3}{|c|}{$\begin{array}{c}R^{2}=.357 \\
F(4,97)=13.492 \\
p \leq .001\end{array}$} & \multicolumn{3}{|c|}{$\begin{array}{c}R^{2}=.101 \\
F(5,96)=2.166 \\
p=.064\end{array}$} & \multicolumn{3}{|c|}{$\begin{array}{c}R^{2}=0.407 \\
F(6,95)=10.870 \\
p \leq .001\end{array}$} \\
\hline
\end{tabular}

Table 3. Multiple Mediation Analysis: Examining the Relationship Between Job Demands (JD) and Instigated Workplace Incivility (WIC) Through Emotional Exhaustion (EE) and Job Satisfaction (JS).

\begin{tabular}{|c|c|c|c|c|}
\hline & \multicolumn{2}{|c|}{ Product of coefficients } & \multicolumn{2}{|c|}{$\mathrm{BCa} 95 \% \mathrm{Cl}$} \\
\hline & $\begin{array}{l}\text { Point estimate of indirect } \\
\text { effect from bootstrapping }\end{array}$ & $S E$ & Lower & Upper \\
\hline $\mathrm{JD} \rightarrow \mathrm{EE} \rightarrow \mathrm{WIC}$ & .368 & .122 & .145 & .628 \\
\hline $\mathrm{JD} \rightarrow \mathrm{EE} \rightarrow \mathrm{JS} \rightarrow \mathrm{WIC}$ & .051 & .032 & .007 & .139 \\
\hline $\mathrm{JD} \rightarrow \mathrm{JS} \rightarrow \mathrm{WIC}$ & .028 & .044 & -.046 & .134 \\
\hline Total & .447 & .130 & .213 & .715 \\
\hline
\end{tabular}

Note. $\mathrm{BCa}=$ bias-corrected and accelerated; $\mathrm{Cl}=$ confidence interval.

all models were supported, and hence, the three paths of interest $\left(\beta_{1}, \beta_{3}\right.$, and $\left.\beta_{6}\right)$ were jointly significant.

The total effect of job demands on instigated workplace incivility was significant in the model adjusting for demographic variables $(\beta=0.447, p \leq .01)$, but was nonsignificant in Model 3 when the mediators were included $\left(\beta_{4}=0.105, p=.457\right)$. However, evidence for full mediation was provided as the total indirect effect (i.e., job demands $\rightarrow$ emotional exhaustion $\rightarrow$ job satisfaction $\rightarrow$ instigated workplace incivility) was significant at $95 \%$ CI [.007, .139].

The serial multiple mediator models contain four indirect effects estimated as products of regression coefficients linking $X$ to $Y$. These indirect effects can be found in the PROCESS output along with 95\% bias-corrected bootstrap CIs based on 5,000 bootstrap samples. Table 3 displays the results of the multiple mediation analysis using the 


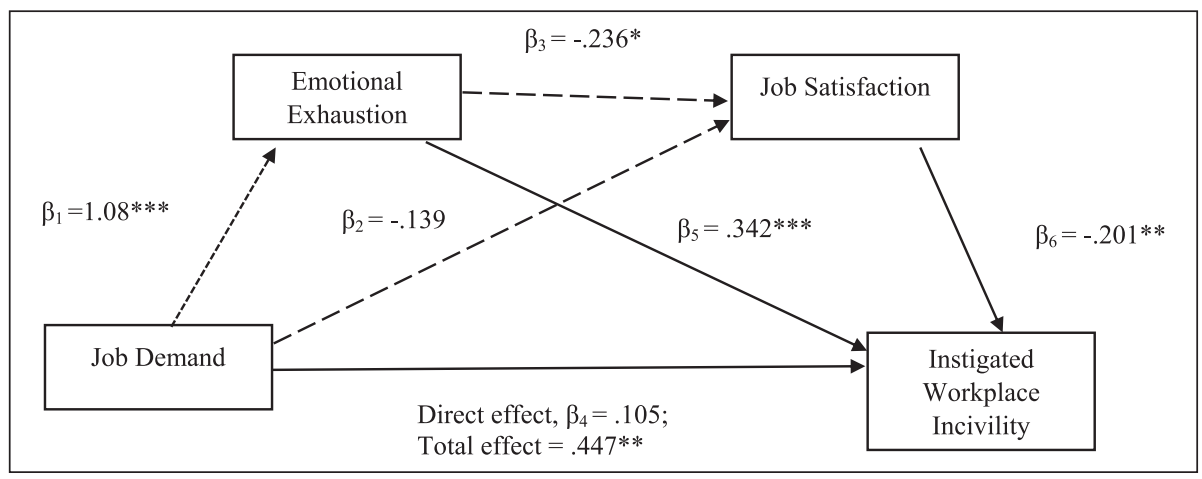

Figure I. Standardized regression coefficients corresponding to the three-path mediation model linking job demands to instigated workplace incivility.

Note. The dotted line represents the path tested in Model I. The dashed lines represent the paths tested in Model 2, while the solid lines represent the paths tested in Model 3.

$*_{p}<.05$. **p $<.01$. **** $<.001$.

bootstrapping technique. Bias-corrected and accelerated CIs calculated were not zero for either of the indirect paths, indicating that the total indirect path of the mediators emotional exhaustion and job satisfaction are both significantly different from zero. The results indicate that together, emotional exhaustion (positively) and job satisfaction (negatively) fully mediate the relationship between job demands and instigated workplace incivility. Additionally, the results of the regression analysis displayed in Table 2 indicate that $40.70 \%$ of the variance in instigated workplace incivility is explained by the multiple mediator models. As such, Hypothesis 4 was supported.

Although age, gender, and employment contract type were included as covariates, the results show that the models were robust, irrespective of these three demographic variables. Figure 1 shows the path of the standardized regression coefficients of the mediation model linking job demands with instigated workplace incivility.

Interestingly, the results also revealed a significant linear relationship between emotional exhaustion and instigated workplace incivility $\left(\beta_{5}=0.342, p<.001\right.$, Model $3)$. We conducted further analyses by treating job satisfaction as Mediator 1 and emotional exhaustion as Mediator 2 in the path of the mediational chain. The results revealed that there was a significant negative linear relationship between job satisfaction and instigated workplace incivility $\left(\beta_{5}=-0.200, p<.01\right)$. The paths of interest of the mediational chain were all significant. Furthermore, the total indirect effect (i.e., job demands $\rightarrow$ job satisfaction $\rightarrow$ emotional exhaustion $\rightarrow$ instigated workplace incivility) was also significant at $95 \%$ CI $[.006, .136]$. Hence, this model also provided evidence for full mediation.

Our study posited that there is a linear association between the paths of the models. However, others studies have found job demands and emotional exhaustion to have a nonlinear association (van Dierendonck \& Nuijten, 2011), specifically when emotional exhaustion was treated as a mediator. To confirm our assumption of linear paths 
in our study, we tested the quadratic terms for emotional exhaustion, job satisfaction, and instigated workplace incivility. Results indicated that the quadratic term assumption was significant for emotional exhaustion, $F(2,99)=25.63, p<.001$, and instigated workplace incivility, $F(2,99)=9.17, p<.001$, but not significant for job satisfaction, $F(2,99)=2.81$. All of our assumptions of the linear relationship between job demands and emotional exhaustion, $F(1,100)=51.48, p<.001$; job satisfaction, $F(1,100)=5.67, p<.05$; and instigated workplace incivility, $F(1,100)=17.61, p<$ .001 , were significant. Therefore, the results of the quadratic terms do not change the overall pattern of our findings.

\section{Discussion}

The present research attempted to explore and understand the antecedents of instigated workplace incivility by examining job demands and the mediating roles of emotional exhaustion and job satisfaction. By combining both AET and the JDC model in our conceptual framework, we found job demands to be positively related to emotional exhaustion, emotional exhaustion to be negatively related to job satisfaction, and job satisfaction to be negatively related to instigated workplace incivility. Emotional exhaustion and job satisfaction acted as sequential mediators in the job demandsinstigated workplace incivility relationship, revealing that the influence of job demands on instigated workplace incivility is through these two mediators. Hence, our findings justified the results of previous research which found a weak relationship between job demands and instigated workplace incivility (Torkelson et al., 2016; van Jaarsveld et al., 2010).

Our results provided empirical support for the theoretically driven three-path mediation model, which links job demands to instigated workplace incivility via emotional exhaustion and job satisfaction. Employees experiencing higher job demands reported higher levels of emotional exhaustion, which, in turn, decreased their level of job satisfaction. The decrease in job satisfaction level leads to instigated workplace incivility. This model treated age, gender, and employment contract type as covariates but found that these three controlled variables did not affect the other variables. Based on our findings, high job demands can be considered a risk factor for deviant behavior such as instigated workplace incivility among academic staff. To remediate such negative behavior in the workplace, an alleviation of emotional exhaustion and boost in job satisfaction are required.

The association between the variables involved in the three-path mediation model were assumed to be linear in our study. However, we acknowledge that others have found nonlinear associations, especially for emotional exhaustion (van Dierendonck \& Nuijten, 2011), where a moderate level of emotional exhaustion may be adaptive. We analyzed a model adjusted for the demographic variables in which we tested the quadratic terms for emotional exhaustion, job satisfaction, and instigated workplace incivility. Our test revealed the quadratic terms to be significant for emotional exhaustion and our quadratic plot revealed that the effects were largely linear but with an asymptotic pattern. These findings indicate that low and medium levels of emotional 
exhaustion as well as instigated workplace incivility were both similarly associated with job demands. Thus, the quadratic results do not change the overall pattern of our findings.

It is worth noting that the mediating effect of emotional exhaustion alone is stronger than the sequential mediating effect of emotional exhaustion and job satisfaction. We conducted further analyses by treating job satisfaction as Mediator 1 and emotional exhaustion as Mediator 2 instead and the results were found to be significant too. One possible explanation is that chronic states of physical and emotional depletion resulting from excessive job demands alone influence deviant behaviors. However, emotional exhaustion could be alleviated if employees like their job or facets of their job, such as the nature of the work or supervision. Thus, job satisfaction could act as a neutralizer in reducing the impact of deviant behavior as our results demonstrated the mediating role of emotional exhaustion in the job demands-instigated workplace incivility to be stronger than the sequential mediating effects of emotional exhaustion and job satisfaction.

\section{Implications of Findings}

Our findings provided some important theoretical implications particularly with regard to AET. We combined AET and the JDC model in our conceptual framework and successfully linked job demands (work environment feature) to instigated workplace incivility (affect-driven behavior) with the use of emotional exhaustion and job satisfaction (affective reaction) as mediators. Such a relationship is in line with van Jaarsveld et al.'s (2010) research that found emotional exhaustion to be a strong mediator on the relationship between customers' incivility and employees' incivility. Hence, our study had successfully underscored the cohesive nature of the variables within the AET framework, providing further support for AET. Our findings also imply that organizations should pay more attention to work environment features as they not only predict work-related attitudes but also affective reactions in employees.

This study has several practical implications and invaluable insights for managers and human resources development practitioners who seek to maintain a positive work climate. Noticeable detrimental effects of workplace incivility have created a need to understand how it occurs and as aptly put by Pearson and Porath (2005), "Where incivility thrives, targets suffer and organizations lose" (p. 16).

The clearest findings in this study are that excessive job demands give rise to emotional exhaustion, which, in turn, leads to instigated workplace incivility. This implies that organizations should take preventative steps in alleviating employees' emotional exhaustion by reducing the pressure of job demands wherever possible. However, considering that many organizations today focus on profit maximization due to a competitive work environment, it might be an unusual step to take in mitigating employees' workload. Nevertheless, organizations could still exhibit more control over their internal work environment compared with their external work environment (Sliter et al., 2011). Additionally, work design intervention prevents job strain that is a result of high job demands (Van Yperen \& Hagedoorn, 2003). Therefore, work tasks and responsibilities 
should be redesigned in a way that provides employees the autonomy to manage and control their work in order to prevent emotional exhaustion. By alleviating emotional exhaustion in employees, instigated workplace incivility would also be reduced.

In addition, managers must delineate ways in which they can identify and preserve the underlying basis of job satisfaction. Our results found job satisfaction to have a significant negative relationship with instigated workplace incivility, indicating that higher levels of job satisfaction lead to reduced instigated workplace incivility among employees. As past researchers have found job characteristics to be significantly linked to job satisfaction (Judge, Bono, \& Locke, 2000), one of the ways to increase the latter is by enriching employees' jobs by providing skill variety, task identity, task significance, autonomy, and feedback (Hackman \& Oldham, 1980). By doing so, employees would find their jobs meaningful and this positive feeling will reduce the rude and discourteous behavior in workplace caused by emotional exhaustion.

\section{Limitations and Future Directions}

There are some limitations in our present study. First, the cross-sectional nature of our data does not allow the judgment of causality nor fully capture the dynamic nature of the job demand-instigated workplace incivility relationship. Future research should use longitudinal data to establish the relationship of these studied variables. Second, the data collected could be subject to self-report method bias, which could result in potential CMV. The results from Harman's ex post one-factor test showed that the first factor accounted for only $27.21 \%$ of the total $59.80 \%$ variance indicated. Thus, CMV was not found to be a serious problem inhibiting the adequate testing of the hypotheses and interpretation of results. However, future research should use more objectives measures of instigated workplace incivility.

A third limitation of our study concerns possible demographic bias as this study only focused on the academic staff working in the education industry across Klang Valley, Malaysia. As such, the results obtained might not be generalizable to the whole population. Additionally, there is little control over the participants selected for this study as snowball sampling method was used. As participants were selected through the referral of existing participants, the true distribution of the population is not known. With that being said, future studies may conduct the research beyond Klang Valley and across different geographical states in Malaysia. Future studies could also investigate instigated workplace incivility among different job industries such as advertising and financial.

A fourth limitation of our study is that only a simple framework was established in the current research. Although the sequential mediating effects of emotional exhaustion and job satisfaction on the job demands-instigated workplace incivility was supported, the results showed the $R^{2}$ value obtained indicated only $40.59 \%$ of the variance of instigated workplace incivility has been explained by the proposed model. As such, we recommend future researchers to include moderators to strengthen and justify the relationships within the framework. For instance, future studies could include individual differences in personalities and traits such as narcissism (Meier \& Semmer, 
2013) or the big five characteristics (Terlecki, 2011) in the model. A moderated mediation framework of such nature could push for a deeper understanding between the relationship of stressors and behaviors by considering individual-based factors.

Finally, as quoted by Anderson (1995), "People will often judge what plausibly might be true rather than try to retrieve exact facts" (p. 215). Hence, it would be worthwhile for future studies to develop a theoretical model that includes supervisors and coworkers for a more accurate assessment of instigated workplace incivility. It would also be interesting to examine experienced, witnessed, and instigated workplace incivility together in developing a more comprehensive framework to understand how workplace incivility occurs and how each person, be it the victim, observer, or instigator, relates to one another. Additionally, future researchers may consider adopting an experimental design study as a way to reduce the likelihood of the data being influenced by participants' biases and implicit theories as well as establish the cause-andeffect among the variables.

\section{Declaration of Conflicting Interests}

The author(s) declared no potential conflicts of interest with respect to the research, authorship, and/or publication of this article.

\section{Funding}

The author(s) received no financial support for the research, authorship, and/or publication of this article.

\section{ORCID iD}

Vui-Yee Koon (D) http://orcid.org/0000-0001-5009-3370

\section{References}

Agervold, M. (2009). The significance of organizational factors for the incidence of bullying. Scandinavian Journal of Psychology, 50, 267-276. doi:10.1111/j.1467-9450.2009.00710.x

Altbach, P. G., \& Knight, J. (2007). The internationalization of higher education: Motivations and realities. Journal of Studies in International Education, 11, 290-305.

Anderson, J. R. (1995). Learning and memory: An integrated approach. New York, NY: Wiley.

Andersson, L. M., \& Pearson, C. M. (1999). Tit for tat? The spiraling effect of incivility in the workplace. Academy of Management Review, 24, 452-471. doi:10.5465/ AMR.1999.2202131

Arokiasamy, L., Ismail, M., Ahmad, A., \& Othman, J. (2009). Background of Malaysian private institutions of higher learning and challenges faced by academics. Journal of International Social Research, 2(8), 60-67.

Baillien, E., De Cuyper, N., \& De Witte, H. (2011). Job autonomy and workload as antecedents of workplace bullying: A two-wave test of Karasek's job demand control model for targets and perpetrators. Journal of Occupational and Organizational Psychology, 84, 191-208. doi:10.1348/096317910X508371

Bakker, A. B., van Veldhoven, M., \& Xanthopoulou, D. (2010). Beyond the demand-control model. Journal of Personnel Psychology, 9, 3-16. doi:10.1027/1866-5888/a000006 
Banks, G. C., Whelpley, C. E., Oh, I.-S., \& Shin, K. (2012). (How) are emotionally exhausted employees harmful? International Journal of Stress Management, 19, 198-216. doi:10.1037/ a0029249

Barling, J. (1996). The prediction, experience, and consequences of workplace violence. In G. R. Vandenbos \& E. Q. Bulatao (Eds.), Violence on the job: Identifying risks and developing solutions (pp. 29-49). Washington, DC: American Psychological Association.

Barling, J., Rogers, A. G., \& Kelloway, E. K. (2001). Behind closed doors: In-home workers' experience of sexual harassment and workplace violence. Journal of Occupational Health Psychology, 6, 255-269. doi:10.1037/1076-8998.6.3.255

Bennett, R. J., \& Robinson, S. L. (2000). Development of a measure of workplace deviance. Journal of Applied Psychology, 85, 349-360. doi:10.1037/0021-9010.85.3.349

Blau, G. (1994). Developing and testing a taxonomy of lateness. Journal of Applied Psychology, 79, 959-970. doi:10.1037/0021-9010.79.6.959

Blau, G., \& Andersson, L. (2005). Testing a measure of instigated workplace incivility. Journal of Occupational and Organizational Psychology, 78, 595-614. doi:10.1348/096317905X26822

Briner, R. B. (1999). The neglect and importance of emotion at work. European Journal of Work and Organizational Psychology, 8, 323-346. doi:10.1080/135943299398212

Bunk, J. A., \& Magley, V. J. (2013). The role of appraisals and emotions in understanding experiences of workplace incivility. Journal of Occupational Health Psychology, 18, 87-105. doi:10.1037/a0030987

Cordes, C. L., \& Dougherty, T. W. (1993). A review and an integration of research on job burnout. Academy of Management Review, 18, 621-656. doi:10.5465/amr.1993.9402210153

Cortina, L. M., Kabat-Farr, D., Leskinen, E. A., Huerta, M., \& Magley, V. J. (2013). Selective incivility as modern discrimination in organizations: Evidence and impact. Journal of Management, 39, 1579-1605. doi:10.1177/0149206311418835

Cortina, L. M., Magley, V. J., Williams, J. H., \& Langhout, R. D. (2001). Incivility in the workplace: Incidence and impact. Journal of Occupational Health Psychology, 6, 64-80. doi:10.1037/1076-8998.6.1.64

Cropanzano, R., Rupp, D. E., \& Byrne, Z. S. (2003). The relationship of emotional exhaustion to work attitudes, job performance, and organizational citizenship behaviors. Journal of Applied Psychology, 88, 160-169. doi:10.1037/0021-9010.88.1.160

De Pater, I. E. (2015, December 3). High cost of rudeness at work. New Straits Times. Retrieved from https://www.nst.com.my/news/2015/12/115233/high-cost-rudeness-work

Demerouti, E., Bakker, A. B., Nachreiner, F., \& Schaufeli, W. B. (2001). The job demandsresources model of burnout. Journal of Applied Psychology, 86, 499-512. doi:10.1037/00219010.86.3.499

Diestel, S., \& Schmidt, K.-H. (2009). Mediator and moderator effects of demands on self-control in the relationship between work load and indicators of job strain. Work \& Stress, 23, 60-79. doi:10.1080/02678370902846686

Doshy, P. V., \& Wang, J. (2014). Workplace incivility: What do targets say about it? American Journal of Management, 14(1/2), 30-42.

Dugguh, S. I., \& Dennis, A. (2014). Job satisfaction theories: Traceability to employee performance in organizations. Journal of Business and Management, 16(5), 11-18.

Estes, B., \& Wang, J. (2008). Workplace incivility: Impacts on individual and organizational performance. Human Resource Development Review, 7, 218-240. doi:10.1177/ 1534484308315565 
Francis, L., Holmvall, C. M., \& O’Brien, L. E. (2015). The influence of workload and civility of treatment on the perpetration of email incivility. Computers in Human Behavior, 46, 191201. doi:10.1016/j.chb.2014.12.044

Glasø, L., \& Notelaers, G. (2012). Workplace bullying, emotions, and outcomes. Violence and Victims, 27, 360-377. doi:10.1891/0886-6708.27.3.360

Glasø, L., Vie, T. L., Holmdal, G. R., \& Einarsen, S. (2011). An application of affective events theory to workplace bullying: The role of emotions, trait anxiety, and trait anger. European Psychologist, 16, 198-208. doi:10.1027/1016-9040/a000026

Griffin, J. M., Greiner, B. A., Stansfeld, S. A., \& Marmot, M. (2007). The effect of self-reported and observed job conditions on depression and anxiety symptoms: A comparison of theoretical models. Journal of Occupational Health Psychology, 12, 334-349. doi:10.1037/10768998.12.4.334

Guest, D. (2004). Flexible employment contracts, the psychological contract and employee outcomes: An analysis and review of the evidence. International Journal of Management Reviews, 5, 1-19. doi:10.1111/j.1460-8545.2004.00094.x

Hackman, J. R., \& Oldham, G. R. (1980). Work redesign. Reading, MA: Addison-Wesley.

Halbesleben, J. R. B., \& Bowler, W. M. (2005). Organizational citizenship behaviors and burnout. In D. L. Turnipseed (Ed.), Handbook of organizational citizenship behavior: A review of "good soldier" activity in organizations (pp. 399-414). Hauppauge, NY: Nova Science.

Henle, C. A., Giacalone, R. A., \& Jurkiewicz, C. L. (2005). The role of ethical ideology in workplace deviance. Journal of Business Ethics, 56, 219-230. doi:10.1007/s10551-004-2779-8

Herschcovis, M., \& Barling, J. (2010). Towards a multi-foci approach to workplace aggression: A meta-analytic review of outcomes from different perpetrators. Journal of Organizational Behavior, 31, 24-44.

Holm, K., Torkelson, E., \& Bäckström, M. (2015). Models of workplace incivility: The relationships to instigated incivility and negative outcomes. BioMed Research International, 2015, 239. doi:10.1155/2015/920239

Hur, W. M., Kim, B. S., \& Park, S. J. (2015). The relationship between coworker incivility, emotional exhaustion, and organizational outcomes: The mediating role of emotional exhaustion. Human Factors and Ergonomics in Manufacturing \& Service Industries, 25, 701-712. doi:10.1002/hfm.20587

Judge, T. A., Bono, J. E., \& Locke, E. A. (2000). Personality and job satisfaction: The mediating role of job characteristics. Journal of Applied Psychology, 85, 237-249.

Karasek, R. A., Jr. (1979). Job demands, job decision latitude, and mental strain: Implications for job redesign. Administrative Science Quarterly, 24, 285-308.

Karatepe, O. M., Yorganci, I., \& Haktanir, M. (2009). Outcomes of customer verbal aggression among hotel employees. International Journal of Contemporary Hospitality Management, 21, 713-733. doi:10.1108/09596110910975972

Kumar, M., Abdul Talib, S., \& Ramayah, T. (2013). Business research methods. New York, NY: Oxford University Press.

Lim, S., Cortina, L. M., \& Magley, V. J. (2008). Personal and workgroup incivility: Impact on work and health outcomes. Journal of Applied Psychology, 93, 95-107. doi:10.1037/00219010.93.1.95

Lim, V. K., \& Teo, T. S. (2009). Mind your e-manners: Impact of cyber incivility on employees' work attitude and behavior. Information \& Management, 46, 419-425. doi:10.1016/j. im.2009.06.006 
Locke, E. A. (1976). The nature and causes of job satisfaction. In M. D. Dunnette (Ed.), Handbook of industrial and organizational psychology (pp. 1297-1349). Chicago, IL: Rand McNally.

Lutgen-Sandvik, P. (2003). The communicative cycle of employee emotional abuse: Generation and regeneration of workplace mistreatment. Management Communication Quarterly, 16, 471-501. doi:10.1177/0893318903251627

MacKinnon, D. P., Lockwood, C. M., Hoffman, J. M., West, S. G., \& Sheets, V. (2002). A comparison of methods to test mediation and other intervening variable effects. Psychological Methods, 7, 83-104. doi:10.1037/1082-989X.7.1.83

Martin, R. J., \& Hine, D. W. (2005). Development and validation of the uncivil workplace behavior questionnaire. Journal of Occupational Health Psychology, 10, 477-490. doi:10.1037/1076-8998.10.4.477

Maslach, C. (1993). Burnout: A multidimensional perspective. In W. B. Schaufeli, C. Maslach, \& T. Marek (Eds.), Professional burnout: Recent developments in theory and research (pp. 19-32). Philadelphia, PA: Taylor \& Francis.

Maslach, C., \& Pines, A. (1977). The burn-out syndrome in the day care setting. Child Care Quarterly, 6, 100-113. doi:10.1007/bf01554696

Meier, L. L., \& Semmer, N. K. (2013). Lack of reciprocity, narcissism, anger, and instigated workplace incivility: A moderated mediation model. European Journal of Work and Organizational Psychology, 22, 461-475. doi:10.1080/1359432X.2012.654605

Meyer, J. P., Allen, N. J., \& Smith, C. A. (1993). Commitment to organizations and occupations: Extension and test of a three-component conceptualization. Journal of Applied Psychology, 78, 538-551. doi:10.1037/0021-9010.78.4.538

Notelaers, G., Baillien, E., Witte, H. D., Einarsen, S., \& Vermunt, J. K. (2013). Testing the strain hypothesis of the demand control model to explain severe bullying at work. Economic and Industrial Democracy, 34, 69-87. doi:10.1177/0143831X12438742

O'Moore, M. (2000). Summary report on the national survey on workplace bullying in Ireland. Dublin, Ireland: Anti-Bullying Research Centre, Trinity College.

Pearson, C. M., Andersson, L. M., \& Porath, C. L. (2000). Assessing and attacking workplace incivility. Organizational Dynamics, 29, 123-137. doi:10.1016/S0090-2616(00)00019-X

Pearson, C. M., \& Porath, C. L. (2005). On the nature, consequences and remedies of workplace incivility: No time for "nice"? Think again. Academy of Management Executive, 19(1), 718. doi:10.5465/ame.2005.15841946

Podsakoff, P. M., \& Organ, D. W. (1986). Self-reports in organizational research: Problems and prospects. Journal of Management, 12, 531-544. doi:10.1177/014920638601200408

Reich, T. C., \& Hershcovis, M. S. (2015). Observing workplace incivility. Journal of Applied Psychology, 100, 203-215. doi:10.1037/a0036464

Reio, T. G., \& Ghosh, R. (2009). Antecedents and outcomes of workplace incivility: Implications for human resource development research and practice. Human Resource Development Quarterly, 20, 237-264. doi:10.1002/hrdq.20020

Rutherford, B., Boles, J., Hamwi, G. A., Madupalli, R., \& Rutherford, L. (2009). The role of the seven dimensions of job satisfaction in salesperson's attitudes and behaviors. Journal of Business Research, 62, 1146-1151. doi:10.1016/j.jbusres.2008.10.019

Saari, L. M., \& Judge, T. A. (2004). Employee attitudes and job satisfaction. Human Resource Management, 43, 395-407. doi:10.1002/hrm.20032

Saif-ur-Rehman, K., Rasli, A., \& Al-Harthey, B. (2011). The psychometric impacts of Karasek's Demands and Control Scale on employees' job dissatisfaction. African Journal of Business Management, 5, 3794-3806. 
Sakurai, K., \& Jex, S. M. (2012). Coworker incivility and incivility targets' work effort and counterproductive work behaviors: The moderating role of supervisor social support. Journal of Occupational Health Psychology, 17, 150-161. doi:10.1037/a0027350

Schilpzand, P., De Pater, I. E., \& Erez, A. (2014). Workplace incivility: A review of the literature and agenda for future research. Journal of Organizational Behavior, 37(Suppl. 1), S57-S88. doi:10.1002/job.1976

Sliter, M. T., Pui, S. Y., Sliter, K. A., \& Jex, S. M. (2011). The differential effects of interpersonal conflict from customers and coworkers: Trait anger as a moderator. Journal of Occupational Health Psychology, 16, 424-440. doi:10.1037/a0023874

Sohail, M. S., Daud, S., \& Rajadurai, J. (2006). Restructuring a higher education institution: A case study from a developing country. International Journal of Educational Management, 20, 279-290. doi:10.1108/09513540610665397

Spector, P. E. (1997). Job satisfaction: Application, assessment, causes, and consequences. Thousand Oaks, CA: Sage.

Swider, B. W., \& Zimmerman, R. D. (2010). Born to burnout: A meta-analytic path model of personality, job burnout, and work outcomes. Journal of Vocational Behavior, 76, 487-506. doi:10.1016/j.jvb.2010.01.003

Tabachnick, B. G., \& Fidell, L. S. (1996). Using multivariate statistics (3rd ed.). New York, NY: HarperCollins.

Taylor, A. B., MacKinnon, D. P., \& Tein, J.-Y. (2008). Tests of the three-path mediated effect. Organizational Research Methods, 11, 241-269. doi:10.1177/1094428107300344

Terlecki, S. A. (2011). Exploring individual and organizational level antecedents of experienced workplace incivility (Unpublished master's thesis). The University of Tennessee, Chattanooga, TN.

Torkelson, E., Holm, K., Bäckström, M., \& Schad, E. (2016). Factors contributing to the perpetration of workplace incivility: The importance of organizational aspects and experiencing incivility from others. Work \& Stress, 30, 115-131. doi:10.1080/02678373.2016.1175524

Tremblay, M. A., \& Messervey, D. (2011). The job demands-resources model: Further evidence for the buffering effect of personal resources. SA Journal of Industrial Psychology, 37(2), 1-10. doi:10.4102/sajip.v37i2.876

van Dierendonck, D., \& Nuijten, I. (2011). The servant leadership survey: Development and validation of a multidimensional measure. Journal of Business and Psychology, 26, 249267. doi:10.1007/s10869-010-9194-1

van Jaarsveld, D. D., Walker, D. D., \& Skarlicki, D. P. (2010). The role of job demands and emotional exhaustion in the relationship between customer and employee incivility. Journal of Management, 36, 1486-1504. doi:10.1177/0149206310368998

Van Yperen, N. W., \& Hagedoorn, M. (2003). Do high job demands increase intrinsic motivation or fatigue or both? The role of job control and job social support. Academy of Management Journal, 46, 339-348.

Vardi, I. (2011). The changing relationship between the scholarship of teaching (and learning) and universities. Higher Education Research \& Development, 30, 1-7. doi:10.1080/07294 360.2011 .536968

Warr, P., Cook, J., \& Wall, T. (1979). Scales for the measurement of some work attitudes and aspects of psychological well-being. Journal of Occupational and Organizational Psychology, 52, 129-148. 
Wegge, J., van Dick, R., Fisher, G. K., West, M. A., \& Dawson, J. F. (2006). A test of basic assumptions of affective events theory (AET) in call centre work. British Journal of Management, 17, 237-254. doi:10.1111/j.1467-8551.2006.00489.x

Weiss, H. M., \& Cropanzano, R. (1996). Affective events theory: A theoretical discussion of the structure, causes and consequences of affective experiences at work. In B. M. Staw \& L. L. Cummings (Eds.), Research in organizational behavior: An annual series of analytical essays and critical reviews (Vol. 18, pp. 1-74). Greenwich, CT: JAI.

Wharton, A. S. (1993). The affective consequences of service work: Managing emotions on the job. Work and Occupations, 20, 205-232. doi:10.1177/0730888493020002004

Zauderer, D. G. (2002). Workplace incivility and the management of human capital. Public Manager, 31(1), 36-42. 